EDYTA ZAWADZKA

Wydział Nauk Pedagogicznych

Akademia Pedagogiki Specjalnej im. M. Grzegorzewskiej

Warszawa

ORCID ID: http://orcid.org/oooo-ooo1-6100-66o7
Forum Pedagogiczne 2018/2

Wpłynęło: 29.05.2018 Zatwierdzono do druku: 26.09.2018 DOI: $10.21697 / \mathrm{fp} .2018 .2 .28$

\title{
Sprawozdanie z posiedzenia Zespołu Pedagogiki Ogólnej Komitetu Nauk Pedagogicznych Polskiej Akademii Nauk (Warszawa, 13 kwietnia 2018 roku)
}

Piąte w obecnej kadencji posiedzenie Zespołu Pedagogiki Ogólnej Komitetu Nauk Pedagogicznych Polskiej Akademii Nauk odbyło się 13 kwietnia 2018 roku w Akademii Pedagogiki Specjalnej im. Marii Grzegorzewskiej w Warszawie. Jego uczestnicy reprezentowali następujące ośrodki naukowe: Akademię Marynarki Wojennej w Gdyni, Akademię Pedagogiki Specjalnej im. Marii Grzegorzewskiej, Chrześcijańską Akademię Teologiczną, Uniwersytet im. Adama Mickiewicza, Uniwersytet im. Kazimierza Wielkiego, Uniwersytet Jagielloński, Uniwersytet Kardynała Stefana Wyszyńskiego, Uniwersytet Łódzki, Uniwersytet Pedagogiczny im. Komisji Edukacji Narodowej w Krakowie, Uniwersytet Warmińsko-Mazurski, Uniwersytet w Białymstoku.

Posiedzenie otworzył przewodniczący ZPO - prof. zw. dr hab. Roman Leppert, który powitał prelegentów oraz uczestników, przekazał im informacje dotyczące czasowego przebiegu spotkania, a następnie zapowiedział wystąpienie prof. Dietricha Bennera (tłumaczone z języka niemieckiego na polski przez ks. dr. hab. prof. UKSW Dariusza Stępkowskiego) na temat Zależności pedagogiczne między kształceniem, moralnościa $i$ demokracja $i$ ich znaczenie w berlińskim projekcie ETIK $i$ badaniach ETIK International.

Punktem wyjścia referatu prof. Dietricha Bennera było rozróżnienie pomiędzy negatywną a pozytywną stroną moralności oraz odczytanie tego zagadnienia w mitach antycznych odnoszących się do moralności i życia moralnego, a także w tradycjach żydowskiej (Dekalogu) oraz chrześcijańskiej. Następnie podjęte zostały zagadnienia związane z kształtowaniem/kształceniem negatywnej i pozytywnej strony sumienia, wynikającymi $\mathrm{z}$ nich zadaniami nauczania etyki w szkole oraz formami nieprofesjonalnego i profesjonalnego działania pedagogicznego w obszarach owych zadań. Do współczesnych celów nauczania etyki powrócono również w dalszej części wypowiedzi, gdzie wychodząc od stwierdzenia o jedności negatywnej strony moralności oraz różnorodności jej pozytywnych stron, określono 
je jako wprowadzenie dorastających w dylematy etyczne oraz przygotowanie tych osób do partycypacji w poszukiwaniu ich rozwiązań. Przedstawiając zróżnicowane jednostronne ujęcia etyki - sokratejskiej, arystotelesowskiej, kantowskiej czy ideologiczno-krytycznej - prelegent sformułował tezę o ich nieprzystawaniu do wskazanych wcześniej zadań.

Kolejna część wystąpienia dotyczyła założeń i wybranych wniosków wypływających z projektu badawczego ETIK, w którym odzwierciedlenie znalazło zarysowane wcześniej ujęcie nauczania etyki w szkole. W zakończeniu prelegent wskazał na możliwość zastosowania pozytywnej i negatywnej strony moralności w procesie rozważania nad tym, co jest działaniem moralnym, etycznym chroniącym przed traktowaniem etyki jako kolonizowania przez inne kultury wyobrażeń moralnych.

W zainicjowanej przez przewodniczącego zespołu dyskusji po referacie prof. Dietricha Bennera głos zabrali: dr Danuta Michałowska, dr hab. prof. APS i prof. ChAT Bogusław Milerski, dr Agata Łopatkiewicz, dr hab. prof. APS Jarosław Gara, dr hab. prof. UŁ Alina Wróbel, prof. dr hab. Janina Kostkiewicz, a podsumował ją prof. zw. dr hab. Roman Leppert. W jej trakcie, tak w refleksjach, jak i zadawanych prelegentowi pytaniach, pojawiły się wątki odnoszące się m.in. do konieczności akcentowania w nauczaniu i wychowaniu etyki aspektu kognitywnego i afektywnego oraz uwzględnienia w refleksji etycznej zróżnicowanych kontekstów życia społecznego, kulturalnego, politycznego, rozróżnienia pomiędzy etyką a moralnością, aktualności dialogu pedagogiki ogólnej z teologią w Niemczech, tła migracyjnego znajdującego odzwierciedlenie w próbie badawczej projektu ETIK, charakteru relacji pomiędzy negatywnym i pozytywnym aspektem wrażliwości moralnej sumienia, kategorii wartości i wartości uniwersalnych, polskich koncepcji teoretycznych, adekwatnych do podjętego w wykładzie zagadnienia form kształtowania moralności/sumienia, związków pomiędzy etyką i pedagogiką oraz metod kształcenia kompetencji moralnych. Komentując wypowiedzi dyskutantów oraz odpowiadając na zadawane przez nich pytania, prof. Benner czynił to, odwołując się jednocześnie do przedstawianego w referacie projektu ETIK, dzięki czemu uczestnikom posiedzenia stworzona została płaszczyzna nie tylko do właściwego zrozumienia warstwy koncepcyjnej projektu, lecz także do pozyskania informacji na temat idei pytań obecnych w kwestionariuszu oraz wybranych wyników i znaczenia kontekstu kulturowego dla takiego ich kształtu. Ponadto wyraźnie wybrzmiała konstatacja dotycząca rozróżnienia pomiędzy przesłankami sytuującymi się u podstaw badań L. Kohlberga i G. Linda, dotyczącymi wyborów moralnych a tymi konstytuującymi omawiany projekt. Wyrażało się to w przekonaniu prof. Bennera, że badania Kohlbergowskie i Lindowskie koncentrują się głównie na rodzaju sądów moralnych, powodach dokonywania pewnych wyborów moralnych, podczas gdy uwaga w projekcie ETIK sfokusowana była na treści wyborów moralnych.

W trakcie przerwy uczestnicy posiedzenia mieli okazję zarówno kontynuować dyskusję w kuluarach, jak i wziąć udział w prowadzonym przez dr. hab. prof. 
APS Jacka Kulbakę zwiedzaniu pokoju pamięci patronki Akademii Pedagogiki Specjalnej - Marii Grzegorzewskiej.

Pierwszym punktem drugiej części spotkania była przygotowana przez prof. dr hab. Janinę Kostkiewicz prezentacja wydanej w 2017 roku nakładem Wydawnictwa Uniwersytetu Jagiellońskiego książki Andrzeja Niesiołowskiego zatytułowanej Zarys Pedagogiki Ogólnej. Prelegentka rozpoczęła od przedstawienia życiorysu Andrzeja Niesiołowskiego i jego dorobku publikacyjnego oraz wyjaśniła okoliczności pozyskania rękopisów powstałych w oflagu, zawierających koncepcję pedagogiki ogólnej. Następnie dokonała charakterystyki pedagogiki ogólnej, opisując m.in. jej przedmiot, zakres zainteresowań, definicję oraz wewnętrzną strukturę, a także kryterium dominującego celu, sytuujące się u podstaw oceny i klasyfikacji koncepcji, nurtów i kierunków rozwoju pedagogiki oraz wyróżnionych systemów, a także kierunków tej nauki. Referentka zasygnalizowała również stosunek Andrzeja Niesiołowskiego wobec innych teoretyków pedagogiki i ich koncepcji pedagogiki ogólnej.

Wystąpienie dr Agaty Łopatkiewicz zatytułowane Problematyka paradygmatu w pedagogice. Analiza wybranych zagadnień stanowiło kolejny punkt popołudniowej części posiedzenia. Referentka rozpoczęła od tezy wyrażającej się w stwierdzeniu o niesłabnącym zainteresowaniu Kuhnowską koncepcją paradygmatu zarówno wśród przedstawicieli filozofii, jak i innych dyscyplin naukowych, również pedagogiki. Następnie dr Łopatkiewicz podzieliła się z uczestnikami posiedzenia wnioskami z przeprowadzonej w ramach rozprawy doktorskiej analizy problematyki paradygmatu w pracach pedagogicznych, wskazując zarówno na specyfikę jego funkcjonowania w analizowanej dyscyplinie, jak i pewne niedostatki w tym zakresie oraz problematyczność (wielo)paradygmatyczności pedagogiki. W konkluzji, na podstawie przeprowadzonych analiz, przedstawione zostały rekomendacje dotyczące konieczności zainicjowania prac o charakterze systematyzacyjnym, ukierunkowanych na uporządkowanie ujęć paradygmatu w pedagogice oraz określenie ograniczeń i trudności wynikających z postrzegania pedagogiki jako nauki wieloparadygmatycznej.

W części podsumowującej posiedzenia przewodniczący Zespołu Pedagogiki Ogólnej zapowiedział dwa wydarzenia naukowe związane z pracami zespołu lub przedmiotem zainteresowań pedagogiki ogólnej. Są to: seminarium dotyczące pedagogiki ogólnej w trzech aspektach, tj. tradycji, transformacji oraz kolonizacji (listopad 2018, Uniwersytet Kazimierza Wielkiego w Bydgoszczy) oraz spotkanie poświęcone zaprezentowaniu w polskim kontekście Jana Patočki jako filozofa, pedagoga oraz odczytaniu myśli pedagogicznej w jego tekstach (listopad 2018, Uniwersytet Kardynała Stefana Wyszyńskiego). 